\title{
WINNING TOURISM DIGITALIZATION OPPORTUNITY IN THE INDONESIA CBT BUSINESS
}

\author{
Setiawan PRIATMOKO* \\ Hungarian University of Agriculture and Life Sciences (MATE), Hungary \\ and STIE Pariwisata API, Jl. Glendongan, Yogyakarta, Indonesia, e-mail: eraynesance@ gmail.com \\ Lóránt Dénes DAVID \\ Hungarian University of Agriculture and Life Sciences (MATE), Hungary; \\ Constantine the Philosopher University in Nitra, Slovakia, e-mail: David.Lorant.Denes@uni-mate.hu
}

\begin{abstract}
Citation: Priatmoko, S., \& Dávid, L.D. (2021). WINNING TOURISM DIGITALIZATION OPPORTUNITY IN THE INDONESIA CBT BUSINESS. GeoJournal of Tourism and Geosites, 37(3), 800-806. https://doi.org/10.30892/gtg.37309-711
\end{abstract}

\begin{abstract}
This research aims to examine the opportunities of Information Communication Technologies (ICT) and its use for the rural tourism businesses. The study used purposive random sampling of presence of tourist villages product in the Online Travel Agency (OTA) application in Indonesia. From the OTA, it can be seen the rural tourism destinations product related offerings suggestion. From the recommended destinations, assessment and comparison is made with the village's official website and other online resources.Tourism villages and their market need to be met comprehensively understanding with OTA app developers to get better future business results.
\end{abstract}

Key words: rural tourism, Community-based tourism (CBT), app developer, Information Communication Technologies (ICT), Online Travel Agency (OTA).

\section{INTRODUCTION}

In the Indonesian National Medium Term Development Plan (RPJMN) 2020-2024, tourism is projected to contribute $5.5 \%$ of Indonesia's GDP. The latest data for 2019 before the Covid pandemic hit shows Indonesia getting 16.106 million foreign tourist visits (BPS-Statistics Indonesia, 2020b) and 282,930 million domestic trips (BPS-Statistics Indonesia, 2020a). This tourism business activity is considered to encourage other business sectors, absorb many workforces, and quickly bring in foreign exchange (Yakup, 2019). The government also plans to develop ten new destinations as a priority by copying Bali Island's success as a tourism paradise island. Tourism development is frequently initiated, supervised, and concluded by central government agencies, particularly in many Asian countries ( $\mathrm{Li}$ et al., 2021). The Indonesian government calls it the $10 \mathrm{New}$ Balis project. Apart from the big tourism development project at the grass-root level, the government is also developing community-based tourism (CBT) in rural tourism or village tourism. This tourist village is a business entity managed by the local community with a core service in the form of products related to tourism by bringing local uniqueness. Tourism businesses for the locals can be owners, managers, and employees; this can also be used to increase the area's life standard (Badurina, 2019). In the last few years, social media and extensive internet networks in remote villages have encouraged tourism village actors to use them as well. About ten years ago, in the early days, tourism village actors used blogs and websites to promote and show their business's existence. Furthermore, social media boom started with the presence of Facebook, the platform became the main media for promotion. Instagram and YouTube are the next social media used by tourism village managers together with Facebook. Blogs began to be abandoned, and the website was used as a window to validate a tourist village's existence. To explore the rural CBT during the pandemic and the value for online communities, this work employs a qualitative study of cases of OTAs specialized in selling tourism related activities in Indonesia. In 2017, with the entry of Online Travel Agencies (OTA) such as TripAdvisor, Traveloka, and Booking.com business models in collaboration with large capital tourism players or individual private businesses such as star hotels and airlines again changed the tourism business map in Indonesia instead of CBT. CBT village businesses in the flow of digital trends are in a situation that can be more profitable if a formula is found for the use of this digital trend. The study questions addressed in this paper are: 1) what are the nowadays and potential future digital prospects in the rural tourism CBT travel industry? 2) How will OTA take a model through ICT in terms of business strategies?

\section{LITERATURE REVIEW}

\section{CBT}

Rural tourism is a business activity in the form of CBT with characteristics that emerge from community development strategies, using tourism activities as an instrument to strengthen the capacity of village community organizations that organize tourism resources with local participation communities (Suansri, 2003). In Indonesia, mostly rural tourism activities are formed as CBT (Priatmoko and Purwoko, 2020) and has popular Indonesian word terminology: "desa wisata" (English: rural

\footnotetext{
* Corresponding author
} 
tourism destination). The CBT contribution allow for the community to derive sustainable attributes that can enable development and release the community from dependence on exogenously-based development initiatives (SETOKOE, 2021). The CBT business also encourages local residents to live more harmoniously by utilizing the assets they have and tends to strengthen the family structure (Chen and Kong, 2021). Villagers led by a group of reformers favoring the village head formed a tourism village entity as a collective agreement (Priatmoko et al., 2021). Local identity and location distinctiveness are connected with tangible and intangible heritage, local cultures and customs, narratives and history, landscape, and communities in creative tourist sectors like CBT (Duxbury et al., 2020). It should aim to sustain the culture and characters of host communities and the landscape and environment (Fatimah, 2015). Community empowerment based on local wisdom through community involvement in tourist villages' development is an important element (Vitasurya, 2016). The Increasing ties between communities are important social capital to develop rural areas' tourism activities (Rindrasih, 2018).

Tourism development would sustain when it is planned strategically to achieve goals that have long-term effects (Atun et al., 2019). Changes that continue to occur in the digital world, especially in Information Communication Technologies (ICT), are becoming necessary. It is believed that globalization is the reason for interest and schemes to shift to various tourism. Context-free/ capacity-free tourism is becoming a supposition to meet different global visitors' expectations in which lifestyles are promoted as not simple illustrations (Atun et al., 2019). Furthermore, digitalizing and their relationship became notable and should prepare tourism businesses for the digital transformation (OECD, 2020).

\section{Modern Tourism Industry}

Digitalizing in tourism industries will provide accessibility to all tourism stakeholders in Indonesia, starting from the aspects of licensing, tourism business activities, and events and providing accessibility for visitors to find information about destinations for visitors in Indonesia (Putra et al., 2018). Over the last few years, marketing tactics for tourism-related businesses have developed, with many more adopting social media and user-generated reviews as marketing tools (Oltra González et al., 2021). Technology embedded in all tourism organizations and stakeholders, destinations will leverage synergies between ubiquitous sensing technology and its social components to support an enriching visitor experience (Buhalis and Amaranggana, 2013). The use of digital technology is also influenced by the number of young travelers who tend to use digital applications (Talwar et al., 2020a). Sometimes a visitor who is driven and thus willing to spend more effort searching for and making decisions for travel decisions is more likely to familiarize themselves with the websites that provide the most helpful info and comprehend the information accessible (Lu et al., 2016).

Cultural efforts could be effectively linked to online tourism service proposals, performing cooperative actions such as co-marketing activities and cross-selling initiatives, which could be maximized if the marketing strategy takes an omnichannel approach (Quaglione et al., 2020). Tourism ecosystems and territories may take into account digital innovation and include smart tourism perspectives. They are sustainability, circular economy perspective, quality of life enhancement, and social values; they should also aim to enrich the tourism experiences and enhance the competitive benefit of smart tourism destinations (Pencarelli, 2020). The internet has evolved into more than a way of life; it has become a key need in modern society, and it has played a critical role in the flow of information for commercial purposes, including OTA. The notion of OTA can be applied to a wide spectrum of businesses, from small to large (Rosyidi, 2019).

\section{OTA}

Online travel bookings can be usually made on a service provider's website, which aggregates the services offered by a number of travel and tourism-related businesses (Talwar et al., 2020b). More ever, the presence of the OTA in the tourism business ecosystem has radically changed the industry into reality on the ground. The travel and tourism industry shows IT's change and its pervasiveness will face other technology waves (Neidhardt and Werthner, 2018).

The influence of the Internet and ICTs on consumers and tourism operators was the focus of the Internet's and ICTs' spread in the tourism sector. The notion was that the introduction of direct online channel opportunities would help enterprises reduce their reliance on traditional middlemen, whose market strength would necessarily have a detrimental impact on both consumer prices and tourism firms' profitability (Quaglione et al., 2020).

The playing field was initially extremely clear: sites maintained by organizations with a commercial stake in the information provided vs sites that did not. Meanwhile, new types of websites have emerged, offering a variety of intermediate services. Some exclusively provide information, while others only provide booking services, but the rest are now mixed (Bronner and de Hoog, 2016). Many traditionally vertically integrated travel companies are now disinvesting in tangible infrastructure to replicate OTAs' more flexible business procedures and non-exclusive virtual partnering model (O’Connor, 2020). In the context of travel, OTAs might be regarded an example of e-commerce or m-commerce. Since 2010, nearly every year, a new booking service agency has emerged, rapidly increasing from 2010 to 2018 (Rosyidi, 2019). They represent a significant departure from the way travel was planned and booked before the internet (Talwar et al., 2020b).

\section{MATERIALS AND METHODS}

This paper uses secondary data from online sources relevant to the rural tourism business and CBT studies, using a searching words of tourist villages in Indonesia in their presence in the OTA application. Previous researches have revealed that one of the most popular online activities is looking for travel-related information (Bronner and de Hoog, 2016). The case study approach will be used. Case studies have a lot of usefulness when it comes to researching complex real-life events in depth (Mohd Noor, 2008). In order to address "how" and "why" inquiries about current events, the case study method is also preferred (Yin, 2003). Furthermore, to build on emergent themes and establish a framework based on the 
findings from the first study, an inductive approach was used (Wynn and Olayinka, 2021). We made a construction of a generalization based on the examination of a group of particulars, an induction activity (Rothchild, 2006). This makes inductive approach as a generalization method. Obtaining knowledge, understanding phenomena, and developing a new theory or model as new knowledge based on the new understanding are all area of utilizing an inductive approach (Park et al., 2020).

The research design process can be seen on Figure 1 below.

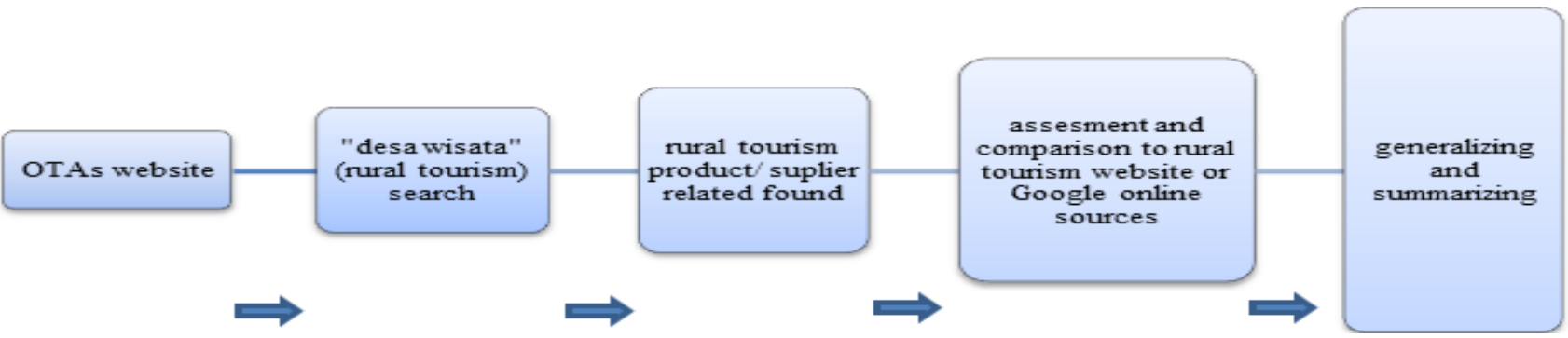

Figure 1. Research Process Flow

Firstly, we are looking for rural tourism destinations in Indonesia through the OTA website. We used "desa wisata" words term since it is a popular term in Indonesia to mention rural tourism destination. From the data displayed by OTA, it can be seen the rural tourism destinations name recommendation. Secondly, we then searched for the official village website and/or other online information resource related to its tourism village based on the OTA's suggested destination. Furthermore, it was then investigated whether the tourism village consciously used OTA to market their goods based on the information gathered from the OTA. We also conduct an assessment of the tourism-related products provided by the tourism village entity or other information found on Google search engine. In this study we examine ten OTAs operated in Indonesia from the results of the DailySocial survey in 2018 (Pusparisa, 2019) and added two popular OTAs in 2020 bringing the total to twelve OTAs. The ten OTAs from the DailySocial survey are: Traveloka.com, Tiket.com, Airy rooms, Agoda, Pegipegi, JD.ID, Zenrooms, RedDoorz, RajaKamar, and GoIndonesia.

From the results of initial observations, it is known that RajaKamar has stopped operating in May 2019 (Syarizka, 2019), Airy rooms stop the operations permanently since May 2020 (Yu, 2020), and GoIndonesia changed its name to myKaha (GoIndonesia.com, n.d.).From existing data, variables related to rural conditions in Indonesian tourism were generalized at a macro level to evaluate the digitalization of the tourism business in Indonesia, especially those considered related to how OTA will impact rural tourism business and the digital environment on the contrary. Literature review and data related to rural conditions in Indonesian tourism were used at a macro level to evaluate the tourism business's digitalization. The results of this analysis will rely on various theories and literature studies to obtain a complete picture of the prospects for Indonesia's digital environment tourism conditions.

\section{RESULTS AND DISCUSSION}

Taking advantage of the digital application developers and owners of the OTA will take this opportunity more seriously. OTA is slowly starting to sell various tourist village tourist destinations, instead it is sometimes a gimmick/addition to support their main sale: accommodation. We looked for information on tourist villages displayed in the twelve OTAs in Indonesia with the keyword "desa wisata (English: rural/ village tourism) is common terminology for Indonesian traveler and tourism enthusiasts. The findings on the twelve OTA websites can be seen on Table 1 as follows.

From the overall OTA, in general we found several product recommendations for names of rural tourist destinations as seen on Table 1 above. However, the names of the "desa wisata" as tourist villages destination refer to hotels, home stays, or properties for rent. Only Traveloka and TripAdvisor offer tour activities with products offered by tour operators. In the next search, we look for the official website or social media belonging to the village that appears on the search page on OTAs In table 1. From the official website or other unofficial sources of information related to the tourist village found on Google, not even a single village sells through OTA. We could not find any OTA shortcut button link on official rural tourism website or on their social media source. The village management sell their product through direct phone, instant messenger, or email. In other words, OTA only uses the name of the village's existence to sell accommodation in the form of a hotel, homestay, or guest house. Although there are business benefits obtained from both parties: the OTA and homestay/guesthouse owners from rooms that have been successfully sold, comprehensive benefit from CBT activities still not found. As we know that CBT is an activity that involves community activities in particular rural areas, not only activities to stay at homestays. It means, the village still not using OTA as a sales distribution channel for all attractions or activities in the tourist village. From the findings of official website information sources or other online sources, tourism villages still prefer direct selling through their personnel rather than through OTA channels. The village CBT management prefer to sell directly as it mentions before and seen on their website or social media channel.

However, certain villages have managed to sell their tourism village products more comprehensively through another OTA platform, as shown in the Tripadvisor.com. They not only sell accommodation but also sell tour packages managed by the villagers. The name of the villages are Nglanggeran and Pentingsari village.

According to BPS data, the number of tourist villages in Indonesia until 2018 is 1,734 villages destination (Reily, 2018). The locations of these tourist villages are scattered in various regions and islands of Indonesia. Domestic trips show a fairly large number from year to year as shown in Figure 2 below. 
Winning Tourism Digitalization Opportunity in the Indonesia CBT Business

Table 1. Desa Wisata Indonesia's OTA Search Result (Source: own research, 2021)

\begin{tabular}{|c|c|c|c|c|c|}
\hline No & OTA & Search Menu & "Desa Wisata" Result Search & Content & Provider \\
\hline \multirow[t]{6}{*}{1} & Traveloka.com & "Xperience" & Gumuk Reco, Semarang, Jawa Tengah & tour package & Tour operator \\
\hline & & & Rumah Dome Teletubies, Sleman Yogyakarta & tour package & Tour operator \\
\hline & & & Rafting Goa Pindul, Yogyakarta & tour package & Tour operator \\
\hline & & & Margolangu, Wonosobo, Jawa Tengah & tour package & Tour operator \\
\hline & & & Lestari Tlogo, Wonosobo, Jawa Tenga & tour package & Tour operator \\
\hline & & & Banana Boat Desa Kumejing, Jawa Tengah & tour package & Tour operator \\
\hline \multirow[t]{3}{*}{2} & TripAdvisor.com & "Where to" & Sembalun Village & tour package & Tour operator \\
\hline & & & Hotel Desa Wisata & hotel & Property owner \\
\hline & & & Desa Wisata Nglanggeran & tour package & Tour operator \\
\hline \multirow[t]{5}{*}{3} & Booking.com & "Where are you going" & Desa Wisata Sukapura, Bromo, East Java & hotel/ homestay & Property owner \\
\hline & & & Hotel Desa Wisata, Jakarta, Indonesia & hotel & Property owner \\
\hline & & & Desa Wisata Ekang, Lagoi, Riau Arch. & hotel/resort & Property owner \\
\hline & & & Homestay Desa Wisata Ngringinan, Bantul & hotel/ homestay & Property owner \\
\hline & & & Desa Wisata Sibetan Homestay, Bali & hotel/ homestay & Property owner \\
\hline \multirow[t]{11}{*}{4} & Tiket.com & "ToDo" & no result & & \\
\hline & & "Hotel" & D'Bamboo Kamp Desa Wisata Ekang & hotel & Property owner \\
\hline & & & Reddoorz Near Desa Wisata Tambi Dieng & hotel/ homestay & Property owner \\
\hline & & & Hotel Desa Wisata Jakarta & hotel & Property owner \\
\hline & & & Homestay \& Cottage Desa Wisata Kreatif & hotel/ homestay & Property owner \\
\hline & & & Desa Wisata Sari Bunihayu & hotel & Property owner \\
\hline & & & Reddoorz Plus Near Desa Wisata Kasongan & hotel & Property owner \\
\hline & & & Spot on 2828 Desa Wisata Gubugklakah & hotel & Property owner \\
\hline & & & Desa Wisata Hotel-Hostel & hotel & Property owner \\
\hline & & & Desa Wisata Sukapura & hotel/ homestay & Property owner \\
\hline & & & Desa Wisata Sibetan Homestay & hotel/ homestay & Property owner \\
\hline 5 & Airyrooms.com & \multicolumn{4}{|c|}{ Not Available, permanently closed since May 31, 2020 due to Covid-19 Pandemic } \\
\hline \multirow[t]{7}{*}{6} & Agoda.com & "Hotels \& Home" & Reddoorz near Desa Wisata Tambi Dieng & \begin{tabular}{|l|l|} 
hotel \\
\end{tabular} & Property owner \\
\hline & & & Hotel Desa Wisata Jakrat & hotel & Property owner \\
\hline & & & Kasongan Travel Village & homestay & Property owner \\
\hline & & & Dbamboo Kamp Desa Wisata Ekang, Bintan & hotel/ resort & Property owner \\
\hline & & & Homestay Desa Wisata Ngringinan & homestay & Property owner \\
\hline & & & Desa Wisata Kreatif Terong, Belitung & hotel/ homestay & Property owner \\
\hline & & & Desa Wisata Pentingsari, Yogyakarta & homestay & Property owner \\
\hline \multirow[t]{12}{*}{7} & Pegipegi.com & "Destination/ hotel name" & Desa Wisata Kungkuk, Malang & hotel & Property owner \\
\hline & & & Desa Wisata Sembalun, Lombok & hotel & Property owner \\
\hline & & & Desa Wisata Guliang Kangin, Bali & hotel & Property owner \\
\hline & & & Desa Wisata Pujon Kidul, Malang & hotel & Property owner \\
\hline & & & Desa Wisata Gerabah Kasongan, Jogja & hotel & Property owner \\
\hline & & & Desa Wisata Sari Bunihayu & hotel & Property owner \\
\hline & & & Desa Wisata Hotel-Hostel Seribu Riam & hotel & Property owner \\
\hline & & & Hotel Desa Wisata, Jakarta & hotel & Property owner \\
\hline & & & Dbamboo Kamp Desa Wisata Ekang, Bintang & hotel & Property owner \\
\hline & & & RedDoorz near Desa Wista Tambi Dieng & hotel & Property owner \\
\hline & & & Krisna Oleh-oleh Khas Bali Desa Wisata & hotel & Property owner \\
\hline & & & Spot on 2828 Desa Wista Gubugklakah & hotel & Property owner \\
\hline 8 & JD.ID & "Hotel"Buy Now Vacation later" & \multicolumn{3}{|l|}{ no result } \\
\hline 9 & Zenrooms.com & search box & \multicolumn{3}{|l|}{ no result } \\
\hline 10 & RedDoorz.com & search box & RedDoorz Near Desa Wisata Tambi Dieng & hotel & Property owner \\
\hline 11 & RajaKamar.com & \multicolumn{4}{|c|}{ Not Available, permanently closed since May 8, 2019} \\
\hline \multirow[t]{6}{*}{12} & myKaha.com & "Hotel" & Hotel Desa Wisata & hotel & Property owner \\
\hline & & & DbambooKamp Desa Wisata Ekang & hotel & Property owner \\
\hline & & & RedDooz near Desa Wisata Kasongan & hotel/ homestay & Property owner \\
\hline & & & RedDoorz Plus near Desa Wisata Osing & hotel/ homestay & Property owner \\
\hline & & & RedDoorz Plus near Desa Wisata Kasongan & hotel/ homestay & Property owner \\
\hline & & & SPOT ON 2828Desa Wisata Gubugklakah & \begin{tabular}{|l|l|} 
hotel \\
\end{tabular} & Property owner \\
\hline
\end{tabular}

With a historic domestic trip number from several previous years and showing a total visit of almost 290 million trips in 2019 for all destinations in Indonesia, of course, rural tourism businesses have the potential to take a percentage share of that number. Despite the main concept of rural tourism is special interest tourism which is different from mass tourism, there will still be demands for many rural CBT destinations. Shifting the type of tourists into small groups or even free individual travelers (FIT) coupled with the post-Covid-19 health protocol will change many things about managing village tourist destinations. Integrating ICT infrastructure, which CBT has long used, will continue to evolve from the blog era to the social media era, and followed to OTA era. Support and collaboration among stakeholders are needed. Community involvement can be used to achieve a power balance and assert local community views over those of developers or local governments ( $\mathrm{Li}$ et al., 2021). In the future, if the forms of agreement regarding the division of labor and profit-sharing within tourism village actors can be formulated, then the use of applications such as OTA that sell CBT destinations will be even more massive. Indeed, it is not easy to define business agreements within community organizations such as CBT in 
rural areas. Talking about money seems to marginalize the meaning of togetherness/ social cohesion for rural communities in Indonesia. Moreover, it will be an obstacle if the context in question is a business that will be related to other party stakeholders who will work together. Thus, enabling capacity building activities and catalyzing connection for knowledge exchanging and partnerships is essential, especially for geographically scattered initiatives (Duxbury et al., 2020). Furthermore, the development of the tourism business should consider the social and cultural capitals held by the community (Rachmawati, 2014). Additionally, this will be both a problem and an opportunity for developers of various ICT applications that will support the meeting of millions of potential visitors and thousands of tourism village business organizations.

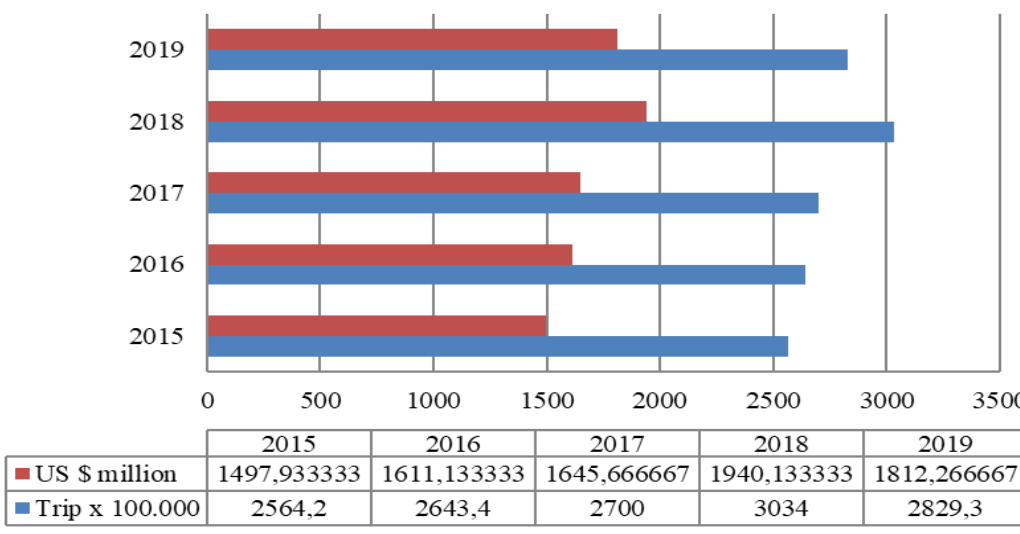

Figure 2. Indonesia Domestic Trip and Revenue (Source: Indonesia Statistics Office-BPS, 2020 (BPS-Statistics Indonesia, 2020a)

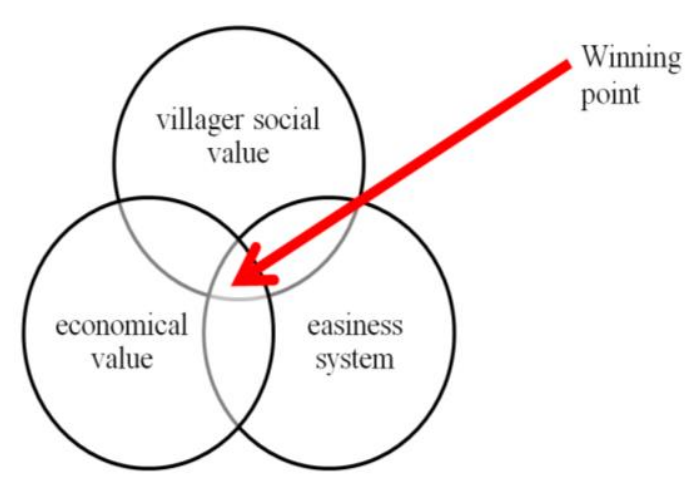

Figure 3. Rural Tourism ICT barriers comply (Source: own research, 2021)

Collaborating with OTA also requires a dynamic pricing strategy understanding. Dynamic pricing refers to a pricing approach in which the price of a product or service changes depending on a variety of criteria. (Malasevska et al., 2020). The strategy for changing and designing dynamic prices for goods and services in tourism village activities needs to be mastered by tourism village actors so that it is easy for third parties such as OTAs to participate in selling the products. The challenges for ICT businesses related to OTA on CBT can be illustrated in figure 3 below. Complying with the village social value barrier, economical barrier, and ease of the business system will make all rural tourism business players winner and give a win-win situation. The above model is almost in line with $\mathrm{Li}$, et al. who stated that barriers to community participation into three groups: constraints at the operational, structural, and cultural levels (Li et al., 2021). As for tourism villages, their future needs related to the ICT function are about selling their products in the form of goods and services while avoiding things that make community cohesion ties loosen. The treatment of digital-based travel businesspeople with business models who are accustomed to solely distributing commissions cannot just be done on CBT. The reason is that there is a tourism village entity formed from the agreement of all village communities. Therefore, the determination of a business model and profit-sharing, and adequate information disclosure between managers is crucial for this digital environment development. With this condition, CBT will be able to respond more quickly to market changes as a result of their greater agility, allowing them to compete more successfully and assure long-term success (O'Connor, 2020).

Many CBT destination locations (more than 1,734 and still counting) and the large number of tourists coupled with tourism as a source of GDP income clearly shows the great need for digitalizing this business. Furthermore, with international travel bans in place, many people mentioned a shift in marketing to local or regional domestic markets (Richards and Morrill, 2021). Thus, rather mature modelling is needed to create an ITC application that can bridge business needs while not destroying the social ties of the village community. The adaptation process in the community is also as the result of a transformation process due to the impact of environmental changes, government policies and people's life patterns on the tourism destination (Marlina et al., 2021). Some ICT applications that bridge in such a way is quite successful in the transportation business are Indonesia's Gojek and Singapore's Grab Company. They can maintain social relations between motorbike taxi drivers while increasing productivity. In early 2021 the company Roatex Zrt. from Hungary, which is engaged in the toll payment system, can also win the tender for all toll road systems in Indonesia digitally with a more advanced navigation system. Transculturation is the process by which disadvantaged or subjugated communities choose from material conveyed to them by dominating urban cultures, sometimes leading to changes in favor of the dominant culture's wishes (Li et al., 2021). Thus, this makes it difficult for the rural community as parties who tend to be in a marginal condition to adjust. Due to low popularity, a lack of e-commence operating experience, and other factors, it is difficult for small, medium-sized, and even some large tourism companies to run their own direct internet channels independently (Long and Shi, 2017).

In general, the formula used by giant e-commerce is to help partners in marketing strategies and deal with calculating profits openly to both parties. IT-based companies such as Gojek and Grab companies get partners who provide goods and services because they are considered capable of helping marketing compared to conventional marketing (Prapti and Rahoyo, 2018). Grab not only optimizes Small to Medium Enterprises/ SMEs kiosk operations by integrating kiosks into their suppliers, but also diversifying their businesses (Pangestu et al., 2020). According to Long and Shi (2017), an OTA's pricing selections are influenced by commissions on unit sales, remuneration, and service costs (Long and Shi, 2017) so pricing strategy is essential. Furthermore, in this digital era, the CBT company in tourist villages will follow a similar approach and will need to be aware of all the opportunities accessible now and take advantage of them in order to 
boost profitability and performance (Stănciulescu and Dumitrescu, 2014). Service quality that reflects professionalism

Table 2. OTA's Quantifying System (Source: own research, 2021)

\begin{tabular}{|c|l|l|}
\hline No. & \multicolumn{1}{|c|}{ Qualitative Value } & \multicolumn{1}{c|}{ Quantitative Approach } \\
\hline 1 & money talk dificulty among villager & pricing disclosure \\
\hline 2 & marketing ability and capacity & dynamic pricing and promotion \\
\hline 3 & capacity building & businesses diversifying \\
\hline 4 & quality judgment & quality rating system \\
\hline 5 & IT system difficulties & friendly User Interface (UI) design \\
\hline
\end{tabular}

increased attention in 2020 was digital nomads. These independent workers, who previously had been a peripheral element in the youth travel market, suddenly became interested as a new source of demand for destinations and travel industry companies (Richards and Morrill, 2021). A huge number of tourism villages and their market in Indonesia need to be met with a comprehensive understanding from OTA app business developers to better future business results. Finally, OTAs should be encouraged appropriately by their rise (Lv et al., 2020).

\section{CONCLUSION}

The tourism business, like other businesses, will experience a cycle of ups and downs depending on macro conditions. Rural tourism can boost business results by combining consumer orientation with the use of ICT as a tool for the value of the bid in the marketplace (Peña and Jamilena, 2011). Community-based tourism businesses in the form of tourist villages in Indonesia require comprehensive digital technology and ICT to encourage business optimization Transparent and mutually beneficial understandings and agreements between OTA and CBT entities need to be explored so that more comprehensive benefits can be achieved. CBT organization could learn from OTAs to provide better marketing and competitive benefits to their partners (Abou-Shouk, 2018). Moreover, OTA needs to engage in a partnership/network with the community for a better marketing efficiency of the rural tourist destination.

The number of tourist villages in Indonesia and the continued growth and the large popularity of the tourist market are challenges and opportunities for ICT to engage with rural tourism stakeholders in Indonesia. One of the development methods in rural areas with established regional identities is to increase their appeal for nonpolluting investments, particularly in the tourism sector (Ilieş et al., 2008). The use of digital technology for optimization and development of tourism village businesses shall pay attention to several barriers which have attention to sustainability both economically and socially. The collaboration between the destination and the OTA will enable them to respond more rapidly to market changes, allowing them to compete more efficiently and ensure long-term success (O'Connor, 2020).

\section{Implications of the study}

This paper's findings offer several standing practical implications to improve the opportunities of existing rural tourism destinations. Findings of possible strategies based on various literature and field observations can provide clues to stakeholders and ICT business players on using their community-based tourism assets to improve the local economy. Quantifying community participation, empowerment, destination linkage, a collaboration between stakeholders, and ICT application as smart tourism implication should be done in future research to bridge understanding with OTA app developers.

\section{Acknowledgement}

Special thanks to the Hungarian University of Agriculture and Life Sciences (MATE), STIE Pariwisata API of Indonesia, Stipendium Hungaricum Scholarship, and Indonesian Ministry of Education \& Culture as sending partner.

\section{REFERENCES}

Abou-Shouk, M.A. (2018). Destination management organizations and destination marketing: adopting the business model of e-portals in engaging travel agents. Journal of Travel and Tourism Marketing, 35(2), 178-188. https://doi.org/10.1080/10548408.2017.1350254

Adam, M., Kee, D.M.H., Junaina, I., Fadhilah, N., Uwais, N., Al Rashidi, F., Al Shammari, H., Quttainah, M.A., Srivastava, A., \& Pandey, R. (2020). The Influence of Customer Satisfaction on Grab Services in Malaysia. International Journal of Tourism and Hospitality in Asia Pasific, 3(2), 26-37. https://doi.org/10.32535/ijthap.v3i2.820

Atun, R.A., Nafa, H., \& Türker, Ö.O. (2019). Envisaging sustainable rural development through 'context-dependent tourism': case of northern Cyprus. Environment, Development and Sustainability, 21(4), 1715-1744. https://doi.org/10.1007/s10668-018-0100-8

Badurina, J.Đ. (2019). Teaching Case Study Mon Perin Ltd.: Example of Community-Owned Tourism. Tourism and Hospitality Management, 25(2), 421-429.

Bronner, F., \& de Hoog, R. (2016). Travel websites: Changing visits, evaluations and posts. Annals of Tourism Research, 57, 94-112. https://doi.org/10.1016/j.annals.2015.12.012

Buhalis, D., \& Amaranggana, A. (2013). Smart Tourism Destinations. In Z. Xiang \& I. Tussyadiah (Eds.), Information and Communication Technologies in Tourism 2014. Springer, Cham. https://doi.org/10.1007/978-3-319-03973-2

Chen, P., \& Kong, X. (2021). Tourism-led Commodification of Place and Rural Transformation Development: A Case Study of Xixinan Village, Huangshan, China. Land, 10(7), 694. https://doi.org/10.3390/land10070694

Duxbury, N., Bakas, F.E., Vinagre de Castro, T., \& Silva, S. (2020). Creative Tourism Development Models towards Sustainable and Regenerative Tourism. Sustainability, 13(1), 2. https://doi.org/10.3390/su13010002

Fatimah, T. (2015). The Impacts of Rural Tourism Initiatives on Cultural Landscape Sustainability in Borobudur Area. Procedia Environmental Sciences, 28(SustaiN 2014), 567-577. https://doi.org/10.1016/j.proenv.2015.07.067

GoIndonesia.com. (n.d.). GoIndonesia.com. Retrieved July 12, 2021, from http://goindonesia.com/

Ilieș, A., Ilieş, D.C., Josan, I., Grama, V., \& Gozner, M. (2008). Romanian Rural Tourism Between Authentic/Traditional and Modern/Contemporary. The Case of Crişana and Maramureş Areas. GeoJournal of Tourism and Geosites Year I, 2(2), $140-148$.

Li, X., Kim, J.S., \& Lee, T.J. (2021). Collaboration for Community-Based Cultural Sustainability in Island Tourism Development: A Case in Korea. Sustainability, 13(13), 7306. https://doi.org/10.3390/su13137306 
Long, Y., \& Shi, P. (2017). Pricing strategies of tour operator and online travel agency based on cooperation to achieve O2O model. Tourism Management, 62, 302-311. https://doi.org/10.1016/j.tourman.2017.05.002

Lu, A.C.C., Gursoy, D., \& Lu, C.Y.R. (2016). Antecedents and outcomes of consumers' confusion in the online tourism domain. Annals of Tourism Research, 57(200), 76-93. https://doi.org/10.1016/j.annals.2015.11.020

Lv, X., Li, N., Xu, X., \& Yang, Y. (2020). Understanding the emergence and development of online travel agencies: a dynamic evaluation and simulation approach. Internet Research, 30(6), 1783-1810. https://doi.org/10.1108/INTR-11-2019-0464

Malasevska, I., Haugom, E., Hinterhuber, A., \& Lien, G. (2020). Dynamic pricing assuming demand shifting : the alpine skiing industry. Journal of Travel \& Tourism Marketing, 37(7), 785-803. https://doi.org/10.1080/10548408.2020.1835787

Marlina, Sumarmi, Astina, I.K., \& Susilo, S. (2021). Social-Economic Adaptation Strategies of Bajo Mola Fishers in Wakatobi National Park. Geojournal of Tourism and Geosites, 34(1), 14-19. https://doi.org/10.30892/GTG.34102-613

Mohd Noor, K.B. (2008). Case Study: A Strategic Research Methodology. American Journal of Applied Sciences, 5(11), $1602-1604$. http://www.gslis.utexas.edu/ ssoy/usesusers/1391d1b.htm\%5Cnhttp://www.sbs.ox.ac.uk/centres/bt/directory/Documents/CaseStudy4 2HBQR11PRINT.pdf\%5Cnhttp://books.google.com/books?id=FzawIAdilHkC\&pgis=1\%5Cnhttp://scielo.iics.una.py/pdf/riics/v8n1/v8n1a09.pdf

Neidhardt, J., \& Werthner, H. (2018). IT and tourism: still a hot topic, but do not forget IT. Information Technology and Tourism, 20(14), 1-7. https://doi.org/10.1007/s40558-018-0115-x

O'Connor, P. (2020). Online tourism and hospitality distribution: a perspective article. Tourism Review, 75(1), $290-293$. https://doi.org/10.1108/TR-06-2019-0216

Oltra González, I., Camarero, C., \& San José Cabezudo, R. (2021). SOS to my followers! The role of marketing communications in reinforcing online travel community value during times of crisis. Tourism Management Perspectives, 39, 100843. https://doi.org/10.1016/j.tmp.2021.100843

Pangestu, M.E., Simandjuntak, D., Damuri, Y.R., Fernandes, A., Handoko, I., Rahman, F., Priyadi, L., Kusumawardhani, S., Perkasa, B. T., Yazid, E.K., \& Phoe, F. (2020). Grab and the Gig Economiy: Strengthening Economic Resilience 2019 Study (Issue June).

Park, D., Bahrudin, F.I., \& Han, J. (2020). Circular Reasoning for the Evolution of Research Through a Strategic Construction of Research Methodologies. International Journal of Quantitative and Qualitative Research Methods, 8(3), 1-23.

Peña, A.I.P., \& Jamilena, D.M.F. (2011). Market orientation adoption in rural tourism: Impact on business outcomes and the perceived value. International Review on Public and Nonprofit Marketing, 8(2), 195-197. https://doi.org/10.1007/s12208-011-0068-7

Pencarelli, T. (2020). The digital revolution in the travel and tourism industry. Information Technology and Tourism, 22(3), 455-476. https://doi.org/10.1007/s40558-019-00160-3

Prapti, R.L., \& Rahoyo. (2018). Dampak Bisnis Kuliner Melalui go Food Bagi Pertumbuhan Ekonomi Di Kota Semarang. Dinamika Sosial Budaya, 20(2), 120-133.

Priatmoko, S., Kabil, M., Purwoko, Y., \& Dávid, L.D. (2021). Rethinking Sustainable Community-Based Tourism: A Villager's Point of View and Case Study in Pampang Village, Indonesia. Sustainability, 13(6), 1-15. https://doi.org/10.3390/su13063245

Priatmoko, S., \& Purwoko, Y. (2020). Does the Context of MSPDM Analysis Relevant in Rural Tourism ?: Case Study of Pentingsari , Nglanggeran, and Penglipuran. International Conference on Creative Economics, Tourism and Information Management (ICCETIM) 2019, Vol. 1-978-989-758-451-0, 15-21. https://doi.org/10.5220/0009857400150021

Pusparisa, Y. (2019). 10 Agen Perjalanan Online Terpopuler. Katadata.Co.Id. https://databoks.katadata.co.id/datapublish/2019/11/12/10agensi-perjalanan-online-pilihan-konsumen\#

Putra, F.K.K., Saepudin, P., Adriansyah, E., \& Adrian, I.G.A.W. (2018). Digital Tourism: A Content Analysis of West Java Tourism

Websites. Journal of Indonesian Tourism and Development Studies, 6(2), 73-84. https://doi.org/10.21776/ub.jitode.2018.006.02.02
Quaglione, D., Crociata, A., Agovino, M., \& Iaia, L. (2020). Cultural capital and online purchase of tourism services. Annals of Tourism Research, 80 (March 2019), 102797. https://doi.org/10.1016/j.annals.2019.102797

Rachmawati, E. (2014). Host Community's Social and Cultural Capital for Ecotourism Development in Indonesia. SHS Web of Conferences, 12, 01035. https://doi.org/10.1051/shsconf/20141201035

Reily, M. (2018). 2018, Potensi Desa Wisata Naik Menjadi 1.734 Unit. Katadata.Co.Id. https://katadata.co.id/ekarina/berita/ 5e9a558d10a92/2018-potensi-desa-wisata-naik-menjadi-1734-unit

Richards, G., \& Morrill, W. (2021). The Challenge of Covid-19 for Youth Travel. Anais Brasileiros de Estudos Turísticos - ABET, 11(Single Issue (2021): Current Topics in Tourism and Thematic Section: "Tourism in times of COVID-19), 1-8. https://periodicos.ufff.br/index.php/abet

Rindrasih, E. (2018). Under the Volcano: Responses of a Community-Based Tourism Village to the 2010 Eruption of Mount Merapi, Indonesia. Sustainability (Switzerland), 10(5). https://doi.org/10.3390/su10051620

Rosyidi, M.I. (2019). Indonesian Online Travel Agencies : Profiling the services, employment, and users. Advances in Social Science, Education and Humanities Research, 259, 211-216.

Rothchild, I. (2006). Induction, Deduction, and the Scientific Method. In Society for the Study of Reproduction (pp. 1-11). http://www.ssr.org/sites/ssr.org/files/uploads/attachments/node/16/rothchild_scimethod.pdf

Setokoe, T.J. (2021). Community-based Tourism: A Panacea for Community Development in Nqileni Village, Eastern Cape, South Africa. Geojournal of Tourism and Geosites, 34(1), 28-32. https://doi.org/10.30892/gtg.34104-615

Stănciulescu, G.C., \& Dumitrescu, F. (2014). Optimizing the IT Structures of Tourism SMEs Using Modern Applications and Resources (Cloud). Procedia Economics and Finance, 15(14), 1769-1778. https://doi.org/10.1016/S2212-5671(14)00653-4

Suansri, P. (2003). Community based tourism handbook. Responsible Ecological Social Tour-REST.

Syarizka, D. (2019). Rajakamar Setop Operasi Karena Kalah Modal? Bisnis.Com. https://teknologi.bisnis.com/read/20190510/ 266/920998/rajakamar-setop-operasi-karena-kalah-modal

Talwar, S., Dhir, A., Kaur, P., \& Mäntymäki, M. (2020a). Why do people purchase from online travel agencies (OTAs)? A consumption values perspective. International Journal of Hospitality Management, 88(May), 102534. https://doi.org/10.1016/j.ijhm.2020.102534

Talwar, S., Dhir, A., Kaur, P., \& Mäntymäki, M. (2020b). Barriers toward purchasing from online travel agencies. International Journal of Hospitality Management, 89(May), 102593. https://doi.org/10.1016/j.ijhm.2020.102593

Vitasurya, V.R. (2016). Local Wisdom for Sustainable Development of Rural Tourism, Case on Kalibiru and Lopati Village, Province of Daerah Istimewa Yogyakarta. Procedia - Social and Behavioral Sciences, 216(October 2015), 97-108. https://doi.org/10.1016/j.sbspro.2015.12.014

Wynn, M., \& Olayinka, O. (2021). E-Business Strategy in Developing Countries: A Framework and Checklist for the Small Business Sector. Sustainability, 13(13), 7356. https://doi.org/10.3390/su13137356

Yakup, A.P. (2019). Pengaruh Sektor Pariwisata Terhadap Pertumbuhan Ekonomi Indonesia [Airlangga]. http://repository.unair.ac.id/ 86231/1/TE. 05-19 Yak p ABSTRAK.pdf

Yin, R.K. (2003). Case Study Research and Applications: Design and Methods. SAGE Publications.

$\mathrm{Yu}$, D. (2020). Indonesian hospitality startup Airy to permanently shut down amid pandemic. Techinasia. Com. https://www.techinasia.com/airy-cease-operations

*** BPS-Statistics Indonesia. (2020a). Domestic Tourism Statistics 2019. BPS-Statistics Indonesia.

*** BPS-Statistics Indonesia. (2020b). Indonesian Economic Report, 2020. In W.P.P. Adi \& S. Ayuni (Eds.), BPS-Statistics Indonesia. BPS-Statistics Indonesia. www.bi.go.id

*** OECD. (2020). OECD Tourism Trends and Policies 2020. OECD Publishing. https://doi.org/10.1787/6b47b985-en

Article history: Received: 29.04.2021 Revised: 29.07.2021 Accepted: 19.08.2021 Available online: 07.09.2021 